\title{
Acute Viral Hepatitis: Simultaneous Infection from Hepatitis A, B and E Viruses
}

\author{
Nazish Butt, M. Ali Khan and Farhan Haleem \\ Gastroenterology Section, Jinnah Postgraduate Medical Centre, Karachi, Pakistan
}

\begin{abstract}
Acute viral hepatitis is a significant health problem in the developing world. Usually, the disease runs a benign course with complete resolution of signs and symptoms within days to weeks. It can be caused by any of the hepatitis viruses as well as other pathogens. Viral hepatitis can also be caused by co-infection from multiple hepatitis viruses, however, this is rare. Here, we report a unique case of acute hepatitis caused by simultaneous infection from Hepatitis A Virus (HAV), Hepatitis B Virus (HBV) and Hepatitis E Virus (HEV). This case is rare as all work-ups for probable causes of acute hepatitis were negative; and the review of the literature showed that such a case had not been previously reported.
\end{abstract}

Key Words: Acute viral hepatitis, HAV, HEV, HBV.

How to cite this article: Nazish Butt, M. Ali Khan, Farhan Haleem. Acute viral hepatitis: Simultaneous infection from hepatitis A, B and E viruses. J Coll Physicians Surg Pak 2019; 29 (Supplement 2):S103-S105.

\section{INTRODUCTION}

Acute viral hepatitis is most commonly caused by HAV, $\mathrm{HEV}$ and HBV; co-infection with HAV-HEV is also common. ${ }^{1}$ It is mostly spread via fecal-oral route with poor sanitation being the major culprit. ${ }^{2}$ On the other hand, HBV has other routes of transmission. The typical symptoms include jaundice, fatigue, nausea, vomiting, lethargy and dark urine. ${ }^{3}$ They usually cause self limiting disease but have been reported to cause atypical manifestations such as fulminant hepatic failure. ${ }^{4}$

The diagnosis of acute viral hepatitis is made on the basis of relevant history, deranged liver function tests (LFTs) and positive serology markers for suspected viral hepatitis. Anti-HAV IgM and anti-HEV IgM using ELISA technique are used to detect acute HAV and HEV infection, respectively5; whereas there are several markers for different stages of infectivity for HBV.

HBV surface antigen (HBsAg) indicates ongoing infection, HBV polymerase chain reaction (PCR) DNA quantitative shows active replication, and $\mathrm{HB}$ core antibody $\lg M$ (anti-HBc lgM) and total (anti-HBc) indicate acute infection. Antibody to surface antigen (Anti HBs) indicates immunity. A positive $\mathrm{HBsAg}$ and anti-HBc IgM confirm the diagnosis of acute hepatitis due to HBV.

\section{CASE REPORT}

A 12-year boy, a madrasa student, with no known comorbids presented to the OPD with complains of

Correspondence to: Dr. M. Ali Khan, Gastroenterology Section,

Ward 23, Jinnah Postgradute Medical Centre, Karachi, Pakistan E-mail: Aleekhan3333@gmail.com

Received: January 03, 2019; Revised: April 20, 2019;

Accepted: May 18, 2019 jaundice and low-grade fever for 15 days. It was associated with lethargy, nausea and fatigue. There was no history of vomiting or diarrhea or the use of quack or herbal medications. Patient did use some over-thecounter pain killers / analgesics in the last 15 days for fever. He used to eat junk food almost on daily basis. Vaccination record was complete with the exception of vaccine for $\mathrm{HBV}$.

On examination, the patient was hemodynamically stable with a fever of $100^{\circ} \mathrm{F}$, mildly jaundiced, pallor was absent as was any stigmata of chronic liver disease. On palpation, tender hepatomegaly was present; liver was palpable 2 finger breadths below the right coastal margin in the mid clavicular line and margins were regular. Spleen was not palpable, neither there were any lymph nodes. Rest of the examination was unremarkable.

Laboratory investigations on admission revealed a hemoglobin $(\mathrm{Hb})$ of $12.8 \mathrm{~g} / \mathrm{dl}$, platelets, $435 \times 109 / \mathrm{L}$, mean corpuscular volume (MCV), $88.9 \mathrm{fL}$, white blood cell count (WBC), 7.95x109/L. total bilirubin, $3.11 \mathrm{mg} / \mathrm{dl}$, direct bilirubin, $1.16 \mathrm{mg} / \mathrm{dl}$, alanine aminotransferase (ALT), $1361 \mathrm{U} / \mathrm{L}(0-43 \mathrm{U} / \mathrm{L})$, aspartate transaminase (AST) $355 \mathrm{U} / \mathrm{L}$ (0-37 U/L), gamma-glutamyl transferase, (GGT), $172 \mathrm{U} / \mathrm{L}$ (0-45 U/L), alkaline phosphatase (ALP), $690 \mathrm{U} / \mathrm{L}$ (up to $600 \mathrm{U} / \mathrm{L}$ for children), albumin, $4.8 \mathrm{~g} / \mathrm{dl}$, INR, 0.99, urea, $18 \mathrm{mg} / \mathrm{dl}$, creatinine, $0.6 \mathrm{mg} / \mathrm{dl}$ and lactate dehydrogenase, (LDH) was $258 \mathrm{U} / \mathrm{L}$ with a corrected reticulocyte count of $1.38 \%$.

Acute viral hepatitis was strongly suspected. Anti-HAV $\operatorname{lgM}$ and anti-HEV IgM both were reactive indicating co-infection. While anti-HCV was non-reactive, HBsAg was positive. On further work-up, PCR for HBV was undetectable, $\mathrm{HBeAg}$ was negative, $\mathrm{HBeAb}$ was positive 
and anti-delta, was negative; all suggestive of chronic HBV carrier state.

As part of work-up for acute HBV hepatitis, HBc IgM was also performed. It was positive indicating acute HBV infection with a simultaneous infection from HAV and HEV. All labs were double checked from a reliable laboratory with confirmation of the results, by a senior pathologist.

Autoimmune profile, serum ceruloplasmin levels, slitlamp examination, 24-hour urinary, copper, chest X-rays, ultrasound (US) whole abdomen, FibroScan, urine detailed report (D/R), urine culture sensitivity $(C / S)$, blood C/S, human immunodeficiency virus (HIV) serology, iron profile, serum B12 levels and RBC folate levels were within normal limits. Indirect and direct Coomb's test were negative.

Patient was treated symptomatically and admitted for observation due to the unique nature of this case. Bed rest was advised. Intravenous fluids along with oral hydration were continued, hepatotoxic drugs such as acetaminophen were strictly prohibited. Supportive measures were taken, when necessary. Patient was only allowed in-house soft diet. The symptoms soon resolved; the LFTs also showed a resolving pattern. Thus, the patient was discharged and monthly followups were planned.

On subsequent follow-ups, the patient was asymptomatic and no hepatic or extra-hepatic manifestations developed. At one-year follow-up, the patient was completely symptom-free, and LFTs were normal. PCR for HBV is still undetectable in line with the chronic carrier state. The FibroScan score was $6.7 \mathrm{Kpa}$. There has been no effect on the quality of life or education of the patient so far.

\section{DISCUSSION}

Acute viral hepatitis secondary to HAV and/or HEV is not uncommon and can be asymptomatic or cause acute hepatic injury with or without a background of cirrhosis. Most of these cases are due to less than ideal sanitary and hygienic conditions. The major route of transmission for the above viruses is feco-oral route. Once considered to be a disease of the developing world, it is now being reported with increasing frequency in some developed countries as well.

While even co-infection of HAV and HEV runs a benign course most of the time, great care and caution should be taken in pregnant patients in whom it can cause fulminant liver failure 6 and all immunocompromised patients, such as those of liver transplant, it may cause graft rejection.

Patients with more than one viral hepatitis infection are usually older, male, harbouring more risk factors for disease acquisition; tend to have worse presentations and outcomes. ${ }^{7}$ With the exception of being male, our patient did not have any of the aforementioned risk factors; and the disease course was benign.

Hepatitis B virus is one of the rarer causes of acute hepatitis and much less prevalent than either HEV or HAV. Most people with acute hepatitis have subclinical disease, which may or may not present with symptoms. Patients may have variable degrees of jaundice, malaise, fatigue, fever, tender hepatomegaly, enlargement of spleen and lymph nodes. ${ }^{8}$

For most patients, the disease resolves completely with only supportive treatment without any significant sequel as was the case with our patient. Some patients may develop chronic hepatitis B; fewer still may develop fulminant hepatic failure leading to death. Most patients that develop chronic hepatitis are older than 22 years and females. The young age of our patient was protective for him. Fulminant hepatic failure usually ensues after ingestion of acetaminophen or other hepatotoxic drugs.

It is often difficult to differentiate between acute and chronic HBV infection. A high IgM anti-HBc and (low) HBV-DNA level $<5.5 \log 10 \mathrm{IU} / \mathrm{mL}$ aid the differentiation of acute hepatitis B from chronic hepatitis B. The sensitivity and specificity for this is high, as previously reported by Park et al. 9

It is possible in the late recovery phase of acute viral hepatitis caused by HBV for the DNA levels to be low enough that they cannot be detected via PCR techniques. ${ }^{10}$ as in this case.

Simultaneous infection with HAV, HEV and HBV has not been previously reported to the best of our knowledge. We assume that the three viruses did not affect each other and the disease outcomes were as if the patient was infected with a singular virus at a time. We would conclude that with the increasing incidence of acute viral hepatitis, screening for all three viruses should be done regularly; perhaps, then, more cases may come to light.

\section{PATIENT'S CONSENT:}

Informed consent was taken from the patient and a parent. Patient confidentiality was made certain. All processes involved and were overseen by a guardian or a parent.

\section{CONFLICT OF INTEREST:}

Authors declared no conflict of interest.

\section{AUTHORS' CONTRIBUTION:}

NB: Supervisor, author, data collection.

MAK: Author, data collection.

$\mathrm{FH}$ : Data collection.

\section{REFERENCES}

1. Jain P, Prakash S, Gupta S, Singh KP, Shrivastava S, Singh DD, et al. Prevalence of hepatitis A virus, hepatitis B virus, hepatitis 
C virus, hepatitis D virus and hepatitis $E$ virus as causes of acute viral hepatitis in North India: A hospital based study. Indian J Med Microbiol 2013; 31:261-5.

2. Yano K. Other viral food poisoning (hepatitis $A$ and E). Nihon Rinsho 2012; 70:1386-90 (Japanese).

3. Tekin R, Yolbas I, Dal T, Demirpençe Ö, Kaya S, Bozkurt F, et al. Evaluation of adults with acute viral hepatitis a and review of the literature. Clin Ter 2013; 164:537-41.

4. Jain J, Jain M. Atypical manifestations of viral hepatitis A and $E$. Trop Doct 2013; 43:17-8.

5. Al-Naaimi AS, Turky AM, Khaleel HA, Jalil RW, Mekhlef OA, Kareem SA, et al. Predicting acute viral hepatitis serum markers (A and $E$ ) in patients with suspected acute viral hepatitis attending primary healthcare centers in Baghdad: A one-year cross-sectional study. Glob J Health Sci 2012; 4: 172-83.
6. De Paschale M, Ceriani C, Romanò L, Cerulli T, Cagnin D, Cavallari $\mathrm{S}$, et al. Epidemiology of hepatitis $\mathrm{E}$ virus infection during pregnancy in Benin. Trop Med Int Health 2016; 21:108-13.

7. Baatarkhuu O, Lee HW, George J, Munkh-Orshikh D, Enkhtuvshin B, Ariunaa S, et al. Acute hepatitis A, B and C but not $D$ is still prevalent in Mongolia: A time trend analysis. Clin Mol Hepatol 2017; 23:147-53.

8. Jindal A, Kumar M, Sarin SK. Management of acute hepatitis B and reactivation of hepatitis B. Liver Int 2013; 33(Suppl 1):164-75.

9. Park JW, Kwak KM, Kim SE, Jang MK, Kim DJ, Lee MS, et al. Differentiation of acute and chronic hepatitis B in IgM anti-HBc positive patients. World J Gastroenterol 2015; 21:3953-9.

10. Anastasiou OE, Widera M, Korth J, Kefalakes $\mathrm{H}$, Katsounas A, Hilgard G, et al. Clinical patterns associated with the concurrent detection of anti-HBs and HBV DNA. $J$ Med Virol 2018; 90:282-90. 